\title{
Basic modeling of the visco elastic behavior of flax fiber composites
}

\author{
DOI: 10.35530/IT.070.04.1512
}

CONSTANTIN STOCHIOIU

STEPHANE FONTAINE

BENOIT PIEZEL

AMEUR CHETTAH

\section{REZUMAT - ABSTRACT}

Modelarea comportamentului viscoelastic al compozitelor din fibră de in

La mijlocul secolului al XX-lea, compozitele armate cu fibre de carbon și de sticlă au devenit populare, fiind pe primul loc în cadrul acestei industrii în curs de dezvoltare. Totuși, acestea au anumite dezavantaje care au condus spre dezvoltarea de materiale noi. Cererile actuale se îndreaptă către materiale ieftine și regenerabile. S-a dovedit că fibrele de in deţin cele mai bune proprietăți mecanice dintre fibrele naturale utilizate ca bio-armături, apropiate de cele ale fibrelor de sticlă. Aceste avantaje, împreună cu o densitate mai scăzută decât cea a sticlei și posibilitatea de reciclare, au făcut ca armarea cu fibre de in să fie un candidat pentru următoarea generație de compozite. Împreună cu aceste puncte forte, vine un comportament care, pentru compozitele menționate mai sus, poate fi adesea neglijat: comportamentul dependent de timp. Obiectivul acestei lucrări este să studieze această proprietate și să propună un model pentru evoluția ei. Compozitul analizat este o rășină epoxidică armată cu fibre lungi de in, orientate la $\pm 45^{\circ}$, pentru a pune în evidenţă comportamentul la forfecare al materialului. Procedura experimentală constă dintr-un test de rezistență la tracțiune pentru a determina proprietățile mecanice ale compozitului, în această direcție și pentru a stabili nivelurile de tensiune pentru testele dependente de timp. În al doilea rând, au fost efectuate teste de fluaj-revenire în patru niveluri, cu un fluaj de o oră și o recuperare de cinci ore. În ultima parte a lucrării este prezentată modelarea liniară a acestui fenomen, bazată pe modelele Zener și Burger.

Cuvinte-cheie: biocompozite, viscoelasticitate, model Zener, model Burger

\section{Basic modeling of the visco elastic behavior of flax fiber composites}

In the middle of the $20^{\text {th }}$ century, fiber reinforced composites became mainstream, with carbon and glass fibers at the forefront of this developing industry. However, they have certain disadvantages which have driven the research towards the discovery of novel materials. Today's demands go towards cheap and renewable materials. It has been proven that flax fiber possesses some of the best mechanical properties of bio-reinforcements, close to the ones of the glass fibers. These advantages, together with a lower density than glass and the possibility of recycling have made the flax fiber reinforcement a candidate for the next generation of composites. Along with these strong points, comes a behavior, which, for the composites mentioned earlier, can often be neglected: the time dependent behavior. The present work aims at studying this property and to propose a basic model for its evolution. The analyzed composite is an epoxy resin reinforced by long flax fibers, oriented at $\pm 45^{\circ}$, which show the shear behavior of the material. The experimental procedure consists of a tensile test to determine the mechanical properties of the composite on this direction and to establish the stress levels for the time dependent tests. Secondly, four levels of creep recovery tests are conducted with a creep of one hour and recovery of five hours. In the last part of the paper, linear modeling of this phenomenon is presented, based on the Zener and Burger models.

Keywords: bio-composites, viscoelasticity, Zener model, Burger model

\section{INTRODUCTION}

Fiber reinforced plastics (FRPs) have been a revolution in the design of structures. The fact that their mechanical properties can be tailored to specific applications is a great advantage over metals and, along with their lower density [1], have led this class of materials to be the preferred choice in certain fields of the industry, such as aerospace, automotive or sports goods [2], where weight is an important factor.

Although they come with a vast variation of properties [3], due to the constituents and the interaction between them, FRPs have been shown to possess one in common: a time varying rigidity [4]. Normally, it is a disadvantage that the material changes its properties in time but, it can be an advantage if one, for example, wishes to use such a material in vibration damping applications [5]. The responsible for this behavior is the plastic matrix and, depending on the reinforcing fiber and its percentage in the composite, it can be significant when long term shape stability is considered. Myiano et al. have shown, by constructing a creep master curve, that an epoxy resin, at $50^{\circ} \mathrm{C}$ can reduce to less than a half its rigidity, over a period of approximately 69 days [6]. Another epoxy resin has been tested by Hiel et al. has shown a similar decrease in rigidity at room temperature [7]. Luo et al. have conducted creep tests on a PMMA resin which have shown, at room temperature, a loss of 
approximately $67 \%$ in rigidity, over a period of 4000 seconds [8].

It is obvious that, for the plastic matrix alone, loads sustained for an extended period of time produce significant change in terms of mechanical properties. In the case of fiber reinforced plastics, on the other hand, the mechanical properties of the matrix play a less significant role. Its function, in the composite, is for fiber protection and stress distribution throughout the material [9]. Thus, the deformations obtained during a creep period are lower in comparison. For example, Tuttle and Brinson have recorded, for a carbon fiber reinforced epoxy resin, an increase in deformation of approximately $10 \%$, after maintaining a constant load for 480 min [10]. Similarly, Mohan et al. have conducted experiments on an epoxy resin glass fiber system [11]. The creep curves that they present show an increase of less than $10 \%$ in one hour of testing, at room temperature.

The examples presented are what can be called a classical composite material, which have been the subject of many studies and have been used in many applications. In the recent years, however, green composites have been a significant subject of research [12-15], with the flax fibers being the most suited for structural applications, in terms of ultimate strength [16-17]. They, however present a more significant visco elastic effect when subjected to high loads [18-19], making it significant when designing structures using flax fiber reinforced composites. From here arises the need to understand and model this behavior.

The current work is focused on simple rheological modeling, with the intention of regarding how well it could be implemented for the design of structures. For the parameter identification, the least squares method has been used with success in other similar works as is the one presented by Houanou [20]. It was adopted and introduced in a MatLab script, as it produces rapid and reliable results and, based on it, an error analysis can be conducted.

\section{MATERIALS AND EQUIPMENT}

For the viscoelastic testing, two samples with the fiber direction of $\pm 45^{\circ}$ were used. They were fabri- cated out of the flax fiber prepreg known commercially as Lineo Flaxpreg T-UD20, through a cycle of thermo-compression at $130^{\circ} \mathrm{C}$ and a pressure of 3 bars applied from $115^{\circ} \mathrm{C}$, followed by a post curing cycle without pressure at the same temperature for a period of two hours.

The first sample was used for a traction test. It was painted on one side with a white coat, followed by random black dots, used for the reading of the deformation (figure 1,a). The recording was made with an INSTRON GOM stereo correlation camera. The other sample was equipped with four strain gages, two mounted on the longitudinal direction and two on the transverse one (figure 1,b). The two pairs were mounted back to back in order to eliminate the possible effect of flexion of the specimen during the creep test. The tensile test was realized with a MTS Criterion C45 tensile testing machine, equipped with a $10 \mathrm{kN}$ load cell and the creep tests with a SHIMADZU AGS-X series equipped with a $5 \mathrm{kN}$ load cell.

During the two types of tests, acoustic emission was recorded from the samples with an AEM Micro 80 acoustic emission system, with two microphones mounted at the extremities of the sample, $100 \mathrm{~mm}$ apart.

\section{EXPERIMENTAL PROCEDURE}

The purpose of the tensile test was to determine the mechanical properties and the shear stress - shear strain curve of the material. This was used to choose the parameters of the creep tests, such as the stress levels. The intention was to determine if it is possible to go up as high as $20 \mathrm{MPa}$ of shear stress, while still in the linear portion of the curve and that the creep experiments would be under the limit of internal damage. It is desirable for this to be the case as the damage of the sample would introduce parasitic deformations which would introduce errors in the model. The stress strain curve can be seen in figure 2 .

It is visible that the material has a linear behavior until approximately $25 \mathrm{MPa}$, thus suggesting the upper limit for the creep tests. The acoustic emission provides the information on the damage which starts at 27,63 MPa. This value is higher than the desired

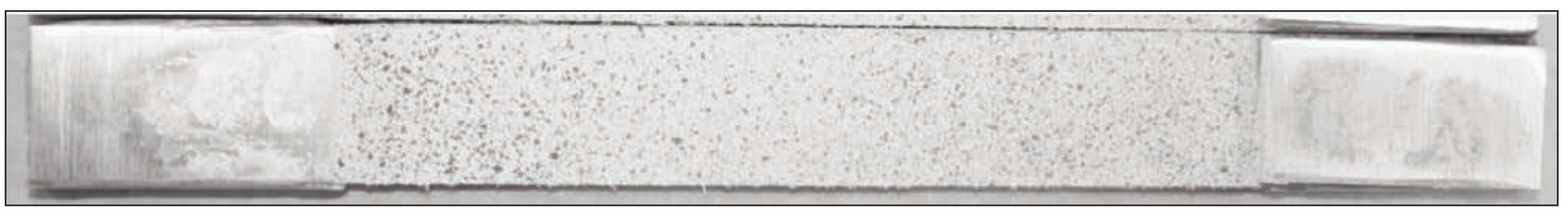

a

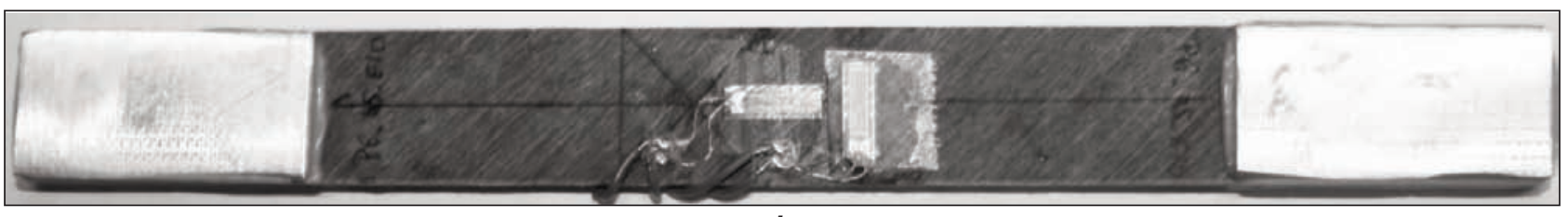

b

Fig. 1. Testing specimens: $a$ - Specimen used for stereocorelation; $b$ - Specimen used for viscoelastic testing 
stress, thus confirming the possibility of charging as high as $20 \mathrm{MPa}$.

This interval has been divided in four, obtaining increments of $5 \mathrm{MPa}$ for each stress level of the creep test. The duration was chosen to be one hour, while de recovery was chosen as 5 hours.

The reading of the four strain gages was made with a frequency of $0,1 \mathrm{~Hz}$. The resulting files were compiled with the help of a MatLab script with which data processing was made. It, firstly, averaged the readings from the pairs of strain gages, thus eliminating the possible flexion induced deformations and then calculated the shear deformation, according to Eq. 1.

$$
\gamma=\varepsilon_{x}-\varepsilon_{y}
$$

where $\gamma$ is the shear deformation, $\varepsilon_{x}$ - the longitudinal deformation and $\varepsilon_{y}$ - the transverse deformation.

It, then, divided the readings by the stress level at which they were recorded. The creep curves are presented in figure 5 . These will be later used to model the behavior.

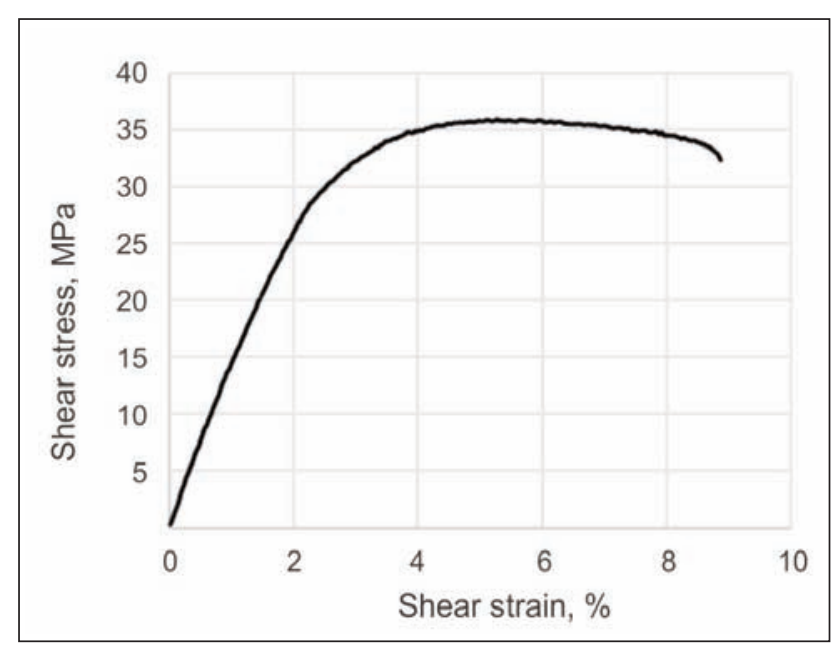

Fig. 2. Shear stress - shear strain curve of the traction test

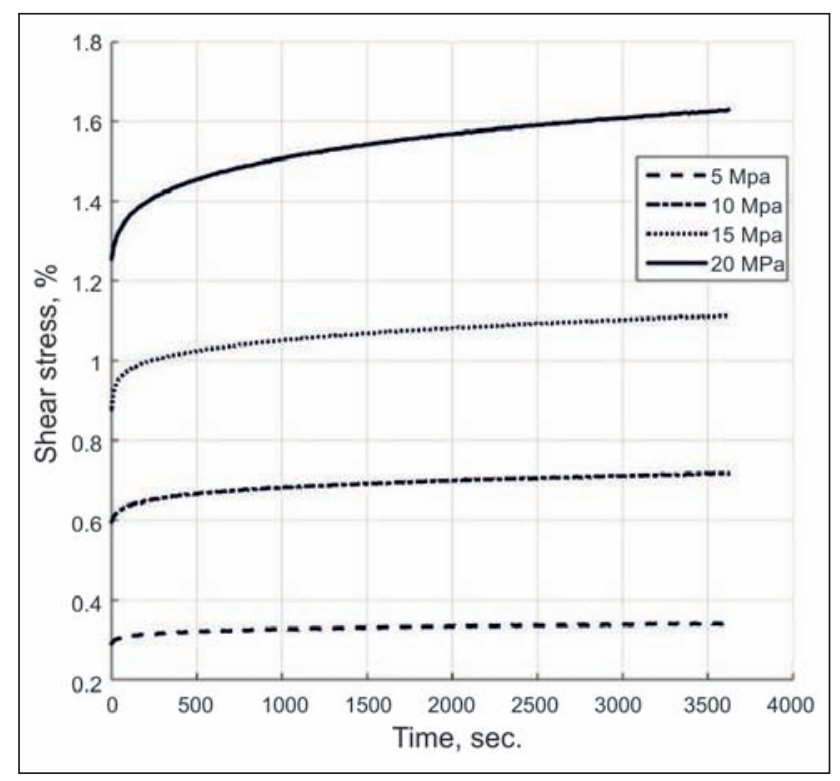

Fig. 3. One-hour creep curves

\section{MODEL DESCRIPTION}

The two models are based on rheology and consist of a series of springs and dashpots mounted in series or in parallel. Each spring comes with a stiffness in the equation and each dashpot with a viscosity. They are presented for a creep test, where the stress is constant.

The Zener model consists of a spring and dashpot mounted in parallel together with a second spring mounted in series to the two (figure 4 , left). Its equation is presented in Eq. 2. The Burger model consists of a Zener one mounted in series with a dashpot (figure 4 , right). Its equation is given in Eq. 3 .

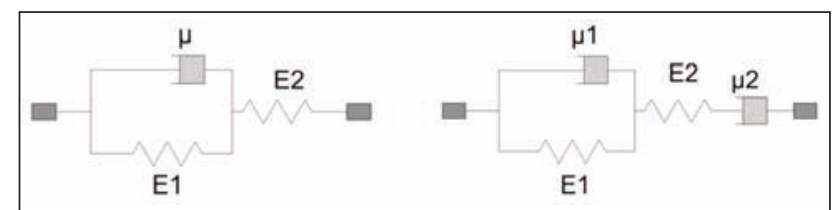

Fig. 4. The rheological models: left - Zener; right - Burger

$$
\begin{gathered}
\varepsilon_{t}=\sigma\left(\frac{E_{1}+E_{2}}{E_{1} E_{2}}-\frac{1}{E_{1}} \cdot \mathrm{e}^{-\frac{\mathrm{t}}{\tau}}\right) \\
\varepsilon_{t}=\sigma\left(\frac{E_{1}+E_{2}}{E_{1} E_{2}}-\frac{1}{\mu_{2}} \cdot t-\frac{1}{E_{1}} \cdot \mathrm{e}^{-\frac{\mathrm{t}}{\tau}}\right)
\end{gathered}
$$

Where $\tau$ is called the reduced time and is calculated as:

$$
\tau=\frac{\mu}{E_{1}}
$$

\section{PARAMETER IDENTIFICATION}

The procedure is made for a creep curve at a low stress level, in the lower parts of the linear domain. For the current work, the $5 \mathrm{MPa}$ creep curve has been used for fitting.

Firstly, at $t=0$, where the creep curve starts, it is possible to determine the instantaneous compliance. By replacing "t" with 0 in the models, $E_{2}$ is calculated.

Further on, an optimization method based on the least squares equation was used. In the case of the Zener model, it was implemented to determine $E_{1}$ and $\mu_{1}$, while for the Burger model, $E_{1}, \mu_{1}$ and $\mu_{2}$. The results of this optimization procedure are given in table 1 and the fitting is shown in figure 5 , for the 5 MPa creep curve.

Table 1

\begin{tabular}{|c|c|c|}
\hline \multicolumn{3}{|c|}{ ZENER AND BURGER MODEL PARAMETERS } \\
\hline Parameter & Zener & Burger \\
\hline $\mathrm{E}_{1}[\mathrm{MPa}]$ & 11,040 & 16,690 \\
\hline $\mathrm{E}_{2}[\mathrm{MPa}]$ & 1,719 & 1,719 \\
\hline$\mu_{1}[\mathrm{MPa} \cdot \mathrm{s}]$ & $5,549,000$ & $2,527,000$ \\
\hline$\mu_{2}[\mathrm{MPa} \cdot \mathrm{s}]$ & - & $84,440,000$ \\
\hline Error $[\%]$ & 3.6 & 1.8 \\
\hline
\end{tabular}




\begin{tabular}{|c|c|c|}
\hline \multicolumn{2}{|c|}{ Table 2} \\
\hline \multicolumn{2}{|c|}{ ERROR CALCULATION FOR THE TWO MODELS } \\
\hline Stress level & Zener (\%) & Burger (\%) \\
\hline $5 \mathrm{MPa}$ & 3.6 & 1.8 \\
\hline $10 \mathrm{MPa}$ & 6.5 & 5.2 \\
\hline $15 \mathrm{MPa}$ & 9.4 & 8.1 \\
\hline $20 \mathrm{MPa}$ & 17.5 & 16 \\
\hline
\end{tabular}

The errors are calculated as the maximum difference between the experimental result and the calculated one.

It is visible that, in the case of the $5 \mathrm{MPa}$ creep curve, the Burger model has a lower error than the Zener one, thus making it more suited for describing the behavior.

Once the parameters were calculated, the remaining three creep curves were compared with the two models. An analysis is made based on the maximum error between the calculated value for the two models and the experimental result. The maximum ones between the experimental curve and the model results are given in table 2 . The creep curves and the two equations are plotted in figure 5 .

It can be seen that, in the case of the first stress level, the error is low but it increases with the increase in stress for each creep level. Both models tend to describe just as well the viscoelastic behavior, with a difference of approximately $1.5 \%$ between the two. They both tend to give results lower than the experimental curves.

The fact that the two models, which are valid in the linear domain tend to diverge from the experimental results is a suggestion that the creep is nonlinear. As a result, these models would need to be adapted to take this nonlinearity into account. One such model is presented by Schapery [21]. It, however, requires a number of seven parameters to be fully defined, out of which, four are non-linear.

\section{CONCLUSIONS}

An experimental procedure of creep recovery tests was conducted in order to identify the visco elastic

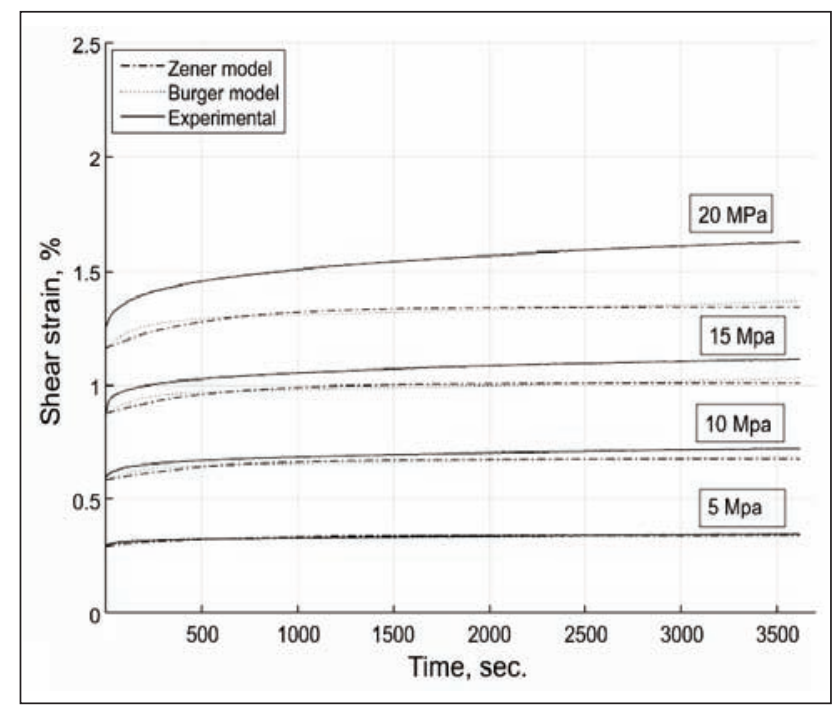

Fig. 5. Creep curves, model and experimental

characteristics of a unidirectional biocomposite laminate. The studied material was a $\pm 45^{\circ}$ fiber direction, which would highlight the shear behavior under a constant stress. The experiments were used to determine, firstly, the shear stress - strain curve, which was used to determine the stress levels for the creep - recovery experiments and, with the help of the latter, calculate the parameters of two rheological models, namely the Zener and Burger ones. A MatLab code was created with this purpose. The method used for the identification was based on a least squares equation. The fitting was made on the lowest level creep curve, which was considered on the linear domain.

Results showed that, for the first creep curve, the two models exhibit a small divergence, while for the other three, this error tended to increase with the increase of the stress level, suggesting that creep occurs in a nonlinear domain.

It is recommended that, in a future work concerning the flax fiber reinforced composites, on this direction, the nonlinearity is to be considered, with the usage of a more complex model, such as the one proposed by Schapery.

\section{BIBLIOGRAPHY}

[1] Flynn, J., Amiri, A., Ulven, C., Hybridized carbon and flax fiber composites for tailored performance, In: Materials \& Design, 2016, 102, pp. 21-29

[2] Wambua, P., Ivens, J., Verpoest, I., Natural fibres: Can they replace glass in fibre reinforced plastics?, In: Composites Science and Technology, 2003, 63, 9, pp. 1259-1264

[3] Meyers, M., Mechanical Behavior of MATERIALS, Cambridge University Press, 2008, ISBN-13: 978-0521866750.

[4] Gutierrez-Lemini, D., Engineering viscoelasticity, 2001

[5] Saunders, D. W., Creep and relaxation of nonlinear viscoelastic materials, 1978

[6] Miyano, Y., Nakada, M., Kasamori, M., Muki, R., Effect of physical aging on the creep deformation of an epoxy resin, In: Mechanics of Time-Dependent Materials, 2000, 4, pp. 9-20

[7] Hiel, C., Cardon, A. H., Brinson, H. F., The nonlinear viscoelastic response of resin matrix composite laminates, 1984 
[8] Luo, W. B., Wang, C. H., Zhao, R. G., Application of time-temperature-stress superposition principle to nonlinear creep of poly(methyl methacrylate), In: Key Engineering Materials, 2007, 340-341, pp. 1091-1096

[9] Mallick, P. K., Fiber-reinforced composites: materials, manufacturing, and design, 2008

[10] Tuttle, M. E., Brinson, H. F., Accelerated viscoelastic characterisation of T300/5208 Graphite - Epoxy laminates, 1985

[11] Mohan, R., Adams, D., Nonlinear creep-recovery response of a polymer matrix and its composites, In: Experimental Mechanics, 1985, no. September, pp. 262-271

[12] Pamuk, G., Ceken, F., Comparison of the mechanical behavior spacer knit cotton and flax fabric reinforced composites, In: Industria Textila, 2013, 64, 1, pp. 3-6

[13] Satyanarayana, K. G., Arizaga, G. G. C., Wypych, F., Biodegradable composites based on lignocellulosic fibers An overview, In: Progress in Polymer Science (Oxford), 2009, 34, pp. 982-1021

[14] Andre, N., Martin, M., Contribution à l'étude de paramètres influençant les propriétés mécaniques de fibres élémentaires de lin - corrélation avec les propriétés de matériaux composites, 2015

[15] Stamboulis, A., Baillie, C. A., Garkhail, S. K., Van Melick, H. G. H., Peijs, T., Environmental durability of flax fibres and their composites based on polypropylene matrix, In: Applied Composite Materials, 2000, 7, 5-6, pp. 273-294

[16] Zhang, Y., Li, Y., Ma, H., Yu, T., Tensile and interfacial properties of unidirectional flax/glass fiber reinforced hybrid composites, In: Composites Science and Technology, 2013, 88, pp. 172-177

[17] Célino, A., Fréour, S., Jacquemin, F., Casari, P., The hygroscopic behavior of plant fibers: a review, In: Frontiers in chemistry, 2013, 1, March 2016, p. 43

[18] Poilâne, C., Cherif, Z. E., Richard, F., Vivet, A., Ben Doudou, B., Chen, J., Polymer reinforced by flax fibres as a viscoelastoplastic material, In: Composite Structures, 2014, 112, 1, pp. 100-112

[19] Varna, J., Sparninš, E., Joffe, R., Nättinen, K., Lampinen, J., Time-dependent behavior of flax/starch composites, In: Mechanics of Time-Dependent Materials, 2012, 16, 1, pp. 47-70

[20] Houanou a K., Tchéhouali, A., Foudjet a E., Identification of Rheological Parameters of the linear Viscoelastic Model of two species of tropical woods (Tectona grandis Lf and Diospyros mespiliformis), In: Research Journal of Engineering Sciences, 2012, 1, 5, pp. 17-24

[21] Schapery a R., Nonlinear viscoelastic and viscoplastic constitutive equations based on thermodynamics, In: Mechanics of Time-Dependent Materials, 1997, 1, pp. 209-240

\section{Authors:}

\section{CONSTANTIN STOCHIOIU ${ }^{1,2}$ BENOÎT PIEZEL ${ }^{2}$ \\ AMEUR CHETTAH ${ }^{2}$ \\ STÉPHANE FONTAINE ${ }^{2}$ \\ HORIA-MIRON GHEORGHIU ${ }^{1}$}

${ }^{1}$ University POLITEHNICA of Bucharest (UPB),

Splaiul Independenței, 313, 060042, Bucharest, Romania

2DRIVE EA 1859, Université Bourgogne Franche-Comté,

49 Rue Mademoiselle Bourgeois, 58027Nevers, France

\section{Corresponding author:}

CONSTANTIN STOCHIOIU

e-mail: C.stochioiu@gmail.com 